\title{
Lactation Ketoacidosis
} A case series

*Abdullah M. Al Alawi, ${ }^{1}$ Usama Al Amri, ${ }^{1}$ Henrik Falhammar ${ }^{2-5}$

$$
\text { حماض كيتوني ناتج من الرضاعة }
$$

عبد الله محمد العلوي، أسامة العامري، وهنريك فالهمر

ABSTRACT: Lactation ketoacidosis is an extremely rare type of high anion gap metabolic acidosis. We report two lactating women who were diagnosed with lactation ketoacidosis. The first patient presented to the Emergency Department at Royal Darwin Hospital, Darwin, Australia, in 2018 with lethargy, nausea and abdominal pain after she commenced a new diet regimen based on three meals of protein per day and free of glucose, gluten and dairy products. The second patient presented to the Emergency Department at Sultan Qaboos University Hospital, Muscat, Oman, in 2018 with headache, severe malaise, epigastric pain and worsening of gastroesophageal symptoms. Blood investigation results showed that both patients had high anion gap metabolic acidosis, ketosis and hypoglycaemia. The patients responded well to intravenous dextrose and resumption of a balanced diet. Both patients were able to continue breastfeeding and remained well on follow-up.

Keywords: Breastfeeding; Starvation; Hypoglycemia; Ketosis; Acid-Base Imbalance; Metabolic Diseases; Ketone Bodies; Fasting; Case Series; Australia; Oman.

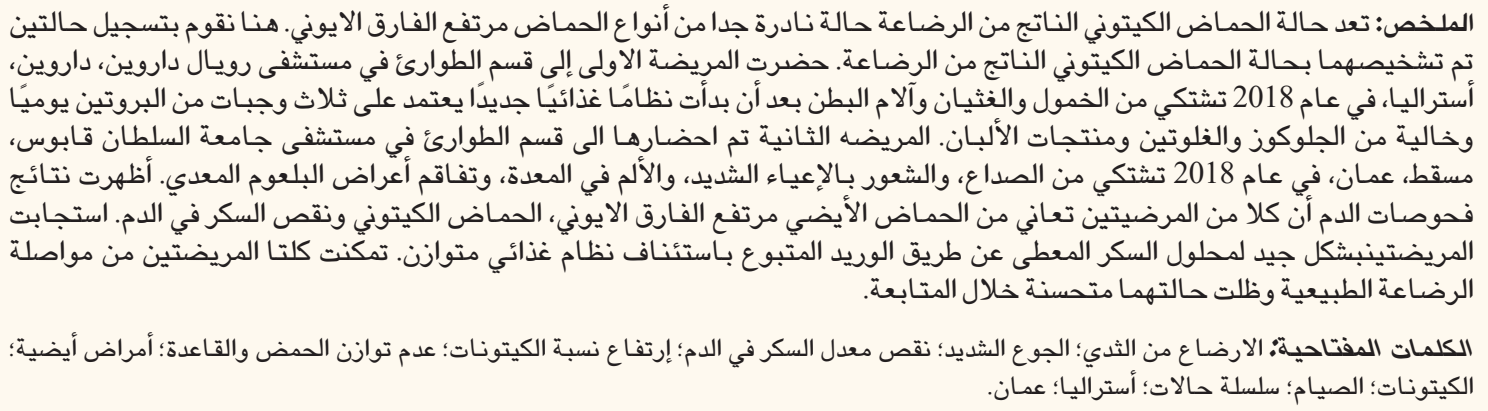

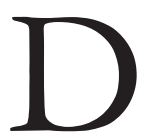
IABETIC KETOACIDOSIS IS THE MOST COMMON cause of high anion gap metabolic acidosis. Other causes of high anion gap metabolic acidosis include lactic acidosis, renal failure, starvation and toxins (e.g. ethanol, methanol, ethylene glycol and salicylate). ${ }^{1}$ Lactation ketoacidosis is an extremely rare cause of high anion gap metabolic acidosis in humans with the first case described in $1982 .{ }^{2}$ Common precipitating factors include change in diet, commencement of intense exercise, skipping meals or intercurrent illness. ${ }^{3}$ Intravenous dextrose, balanced diet and treatment underlying acute illness are the main treatments for this condition. This condition carries a good prognosis and thus far there is no reported mortality in the literature. . $^{3,4}$

\section{Case One}

A 35-year-old lactating Caucasian woman presented to the Emergency Department at Royal Darwin Hospital, Darwin, Australia, in 2018 with a four-day history of lethargy and abdominal pain associated with nausea but no vomiting. She denied any history of altered bowel habits, urinary symptoms, fever or cough. She was breastfeeding her five-month-old healthy infant every 4-6 hours. Recently, she had changed her diet to a glucose-, gluten- and dairy-free diet. Her meals consisted of protein shakes three times per day. During the same period, she resumed her work as a fitness instructor and was doing moderate exercise twice per week [Table 1]. 
Table 1: Clinical characteristics, presentation and treatment of two cases diagnosed with lactation ketoacidosis

\begin{tabular}{|c|c|c|}
\hline & Case one & Case two \\
\hline Ethnicity & Caucasian & Arab \\
\hline $\begin{array}{l}\text { Age of the } \\
\text { patient in } \\
\text { years }\end{array}$ & 35 & 30 \\
\hline $\begin{array}{l}\text { Weight of the } \\
\text { patient in } \mathrm{kg}\end{array}$ & 57.2 & 63 \\
\hline $\begin{array}{l}\text { Age of the } \\
\text { infant in } \\
\text { months }\end{array}$ & 5 & 12 \\
\hline $\begin{array}{l}\text { Precipitating } \\
\text { factor }\end{array}$ & $\begin{array}{l}\text { - Protein based } \\
\text { diet; free of sugar, } \\
\text { dairy products and } \\
\text { gluten } \\
\text { • Exercise }\end{array}$ & $\begin{array}{l}\text { - Significant } \\
\text { reduced oral } \\
\text { intake due to } \\
\text { worsening of } \\
\text { gastroesophageal } \\
\text { reflux symptoms } \\
\text { - Skipped lunch } \\
\text { meals }\end{array}$ \\
\hline Presentation & $\begin{array}{c}\text { Lethargy, nausea } \\
\text { and abdominal } \\
\text { pain }\end{array}$ & $\begin{array}{c}\text { Headache, severe } \\
\text { malaise and } \\
\text { epigastric pain }\end{array}$ \\
\hline Treatment & $\begin{array}{c}\text { Intravenous } \\
\text { dextrose }\end{array}$ & $\begin{array}{l}\text { - Intravenous } \\
\text { dextrose } \\
\text { - Proton pump } \\
\text { inhibitor }\end{array}$ \\
\hline $\begin{array}{l}\text { Duration of } \\
\text { recovery in } \\
\text { hours }\end{array}$ & 24 & 24 \\
\hline Breastfeeding & Continued & Continued \\
\hline
\end{tabular}

Her past medical history included well-controlled asthma and iron-deficiency anaemia for which she had been prescribed a fluticasone propionate inhaler and ferrous sulphate, respectively. She had undergone an emergency lower segment caesarean section (LSCS) five months prior due to obstructed labour; the preand post-natal period were unremarkable. This had been her second LSCS for the same indication. There was no history of ethanol consumption, smoking or illicit substance use.

On physical examination, she appeared unwell, dehydrated and lethargic but was alert and oriented. Her weight was $57.2 \mathrm{~kg}$, blood pressure was 110/68 $\mathrm{mmHg}$ and she had a heart rate of 98 beats/minute. Oxygen saturation was $100 \%$ at room air and she was afebrile. The remaining clinical examination was unremarkable. Blood investigations showed high anion gap metabolic acidosis and high capillary ketones [Table 2].

She was given $25 \mathrm{~mL}$ of $50 \%$ dextrose intravenously, followed by $1 \mathrm{~L}$ of $5 \%$ dextrose infusion. In addition, she was given antiemetics and advised to eat regular meals as tolerated. The patient continued to breastfeed her infant. Her symptoms and ketoacidosis improved dramatically over 24 hours and she was
Table 2: Biochemistry results of two cases at initial presentation who were diagnosed with lactation ketoacidosis

\begin{tabular}{|c|c|c|c|}
\hline Investigation & $\begin{array}{l}\text { Case } \\
\text { one }\end{array}$ & $\begin{array}{l}\text { Case } \\
\text { two }\end{array}$ & $\begin{array}{l}\text { Reference } \\
\text { range }\end{array}$ \\
\hline $\mathrm{pH}$ & 7.26 & 7.21 & $7.3-7.4$ \\
\hline Bicarbonate in $\mathrm{mmol} / \mathrm{L}$ & 12.3 & 14.9 & $21.0-28.0$ \\
\hline Base excess in $\mathrm{mmol} / \mathrm{L}$ & -13.5 & 12.6 & $-2-2$ \\
\hline Anion gap in $\mathrm{mmol} / \mathrm{L}$ & 20.3 & 24 & $8-12$ \\
\hline $\begin{array}{l}\text { Measured serum } \\
\text { osmolality in } \mathrm{mmol} / \mathrm{kg}\end{array}$ & 277.4 & - & $275-295$ \\
\hline $\begin{array}{l}\text { Calculated serum } \\
\text { osmolality in } \mathrm{mmol} / \mathrm{kg}\end{array}$ & 284 & 300 & $275-295$ \\
\hline $\begin{array}{l}\text { Capillary ketones in } \\
\mathrm{mmol} / \mathrm{L}\end{array}$ & 4.8 & - & $<0.6$ \\
\hline Urine dipstick & - & $\begin{array}{l}+++ \\
\text { ketones }\end{array}$ & 0 \\
\hline Lactate in $\mathrm{mmol} / \mathrm{L}$ & 1 & 0.7 & $1.5-2.5$ \\
\hline Glucose in $\mathrm{mmol} / \mathrm{L}$ & 2.9 & 2.9 & $\begin{array}{l}3.9-5.8 \\
\text { (fasting) }\end{array}$ \\
\hline Sodium in $\mathrm{mmol} / \mathrm{L}$ & 138 & 146 & $135-145$ \\
\hline Potassium in $\mathrm{mmol} / \mathrm{L}$ & 4.2 & 4.1 & $3.5-4.5$ \\
\hline Chloride in $\mathrm{mmol} / \mathrm{L}$ & 109 & 108 & $98-106$ \\
\hline Urea in mmol/L & 4.9 & 4.7 & $2.5-7.0$ \\
\hline Creatinine in $\mu \mathrm{mol} / \mathrm{L}$ & 74 & 55 & $50-100$ \\
\hline $\begin{array}{l}\text { Total carbon dioxide in } \\
\mathrm{mmol} / \mathrm{L}\end{array}$ & 12 & - & $22-32$ \\
\hline Haemoglobin in g/dL & 15.3 & 10.7 & $11.5-16.5$ \\
\hline Platelets in $\times 10^{9} / \mathrm{L}$ & 199 & 302 & $150-450$ \\
\hline $\begin{array}{l}\text { White cell count in } \times \\
10^{9} / \mathrm{L}\end{array}$ & 4.7 & 7.2 & $4-11$ \\
\hline Albumin in $\mathrm{g} / \mathrm{L}$ & 49 & 37 & $37-48$ \\
\hline $\begin{array}{l}\text { Corrected calcium in } \\
\mathrm{mmol} / \mathrm{L}\end{array}$ & 2.28 & 2.01 & $2.10-2.60$ \\
\hline Magnesium in mmol/L & 0.81 & 0.72 & $0.70-1.10$ \\
\hline Phosphate in $\mathrm{mmol} / \mathrm{L}$ & 1.31 & 0.69 & $0.75-1.50$ \\
\hline $\begin{array}{l}\text { Total bilirubin in } \\
\mu \mathrm{mol} / \mathrm{L}\end{array}$ & 20 & 4 & $<21$ \\
\hline $\begin{array}{l}\text { Alkaline phosphatase } \\
\text { in } U / L\end{array}$ & 91 & 29 & $30-110$ \\
\hline $\begin{array}{l}\text { Gamma glutamyl } \\
\text { transferase in } U / L\end{array}$ & 10 & - & $<43$ \\
\hline $\begin{array}{l}\text { Alanine } \\
\text { aminotransferase in } \\
\mathrm{U} / \mathrm{L}\end{array}$ & 28 & 14 & $5-42$ \\
\hline Total protein in $\mathrm{g} / \mathrm{L}$ & 84 & 73 & $64-84$ \\
\hline $\begin{array}{l}\text { Glycosylated } \\
\text { haemoglobin in percent }\end{array}$ & 5.4 & 5.5 & $4.3-5.7$ \\
\hline
\end{tabular}


discharged with the advice to eat regular meals consisting of a balanced diet. Her venous blood gas on discharge had almost normalised at $\mathrm{pH} 7.38$ with an almost normal bicarbonate value of $20.4 \mathrm{mmol} / \mathrm{L}$ (normal range: $21.0-28.0 \mathrm{mmol} / \mathrm{L}$ ) and a ketone value of $0.3 \mathrm{mmol} / \mathrm{L}$ (normal range: $<0.6 \mathrm{mmol} / \mathrm{L}$ ). After excluding other causes of high anion gap metabolic acidosis, the diagnosis of lactation ketoacidosis was made. She was well and was breastfeeding on followup four weeks later.

\section{Case Two}

A 30-year-old lactating Arab woman presented to the Emergency Department at Sultan Qaboos University Hospital, Muscat, Oman, in 2018 with headache, severe malaise and epigastric pain that had persisted for one day. In addition, she had worsening of her gastroesophageal reflux symptoms and significantly reduced oral intake over the preceding four days. She was breastfeeding her 12-month-old infant. Her pregnancy had been uneventful and she had delivered a normal baby at full term. She had an abortion two years prior. With regards to her gastrointestinal issue, she had chronic gastroesophageal reflux for more than 10 years that had been treated with antacids previously but had never been investigated thoroughly. The gastroesophageal reflux had worsened over the last four months prior to presentation and she developed dysphagia to solid food. Furthermore, she had struggled to swallow a semi-solid and fluid diet for four days prior to presentation. She continued breastfeeding five times per day. In addition, she was employed full-time in an office and she would skip her lunch meals [Table 1]. There was no history of alcohol consumption, smoking or illicit substance use.

On presentation, she looked dehydrated, was afebrile, alert and oriented. Her blood pressure was $125 / 77$, with a heart rate of 92 beats/minute, a respiratory rate of 19 breaths/minute, a weight of $63 \mathrm{~kg}$, a height of $160 \mathrm{~cm}$ and a body mass index of $24.6 \mathrm{~kg} / \mathrm{m}^{2}$. Abdominal examination revealed mild epigastric tenderness, soft abdomen and no organomegaly. Otherwise, the clinical examination was unremarkable. Blood investigations revealed high anion gap metabolic acidosis, positive urinary ketones and hypoglycaemia [Table 2]. Other investigations including an electrocardiogram, chest X-ray and urine drug abuse screening were unremarkable.

After excluding all causes of high anion gap metabolic acidosis, a diagnosis of lactation ketoacidosis was made and the patient was given $50 \mathrm{~mL}$ of $50 \%$ dextrose intravenously to treat hypoglycaemia followed by a $10 \%$ dextrose infusion. She was admitted to a high dependency unit for close monitoring. Her electrolyte derangements were corrected and she was given intravenous esomeprazole to alleviate gastroesophageal symptoms. An upper gastrointestinal scope examination showed severe reflux oesophagitis with ulceration involving the lower third of the oesophagus. The ketoacidosis resolved within 24 hours and the patient had a remarkable improvement in her symptoms (i.e. headache and malaise). However, $10 \%$ dextrose infusion was continued for another 72 hours when she was able to tolerate an oral diet. The patient opted to continue breastfeeding due to the infant's history of cow's milk formula intolerance. Also, she was counselled by a dietician regarding her calorie intake and was advised to have regular meals. The patient was discharged with esomeprazole and a plan for a follow-up upper gastrointestinal scope examination and an oesophageal manometry. The patient remained well and reported an improvement of the gastroesophageal reflux upon follow-up.

\section{Discussion}

High anion gap metabolic acidosis is a common manifestation of different diseases. Diabetic ketoacidosis is the most common cause of high anion gap metabolic acidosis. Other causes include renal failure, lactate acidosis, toxins (e.g. ethanol, methanol, ethylene glycol or salicylate) and starvation.,

Ketone bodies are converted into energy when the body is running short of glucose. There are three types of ketone bodies: 1) acetoacetate; 2) $\beta$-hydroxybutyrate; and 3 ) acetone. ${ }^{7}$ During a period of fasting, high levels of glucagon and low levels of insulin induce the activity of the enzyme lipoprotein lipase which works on fat stores to release glycerol and long-chain fatty acids. ${ }^{8}$ Those metabolites are processed in the hepatocyte's mitochondria and converted into acetyl-coenzyme A (Acetyl-CoA) through hepatic beta-oxidation. Due to decreased glucose availability, the Acetyl-CoA will be largely used in the ketogenic pathway to produce ketone bodies instead of entering the Krebs cycle. ${ }^{9}$ Other hormones such as glucagon, cortisol, thyroid hormones and catecholamines facilitate ketogenesis. ${ }^{10}$ After three days of starvation, the body maximises the ketones body production, however, significant ketoacidosis requires more than 14 days of starvation to occur in otherwise healthy individuals. ${ }^{11}$

Bovine ketoacidosis is a well-known disease in lactating ruminants, especially in dairy cows. It typically occurs during early lactation when the glucose requirement for milk production exceeds the amount 
of the body's carbohydrate and glycogen stores. ${ }^{12}$ As a result, gluconeogenesis accelerates to meet the demand for milk production, especially in high-yield dairy cows. ${ }^{4}$ Cattle with lactation ketoacidosis may show reduced feeding, reduced milk production, hypoactivity, irritability and abnormal licking and chewing. ${ }^{13,14}$

In cows, intravenous administration of 50\% dextrose is a common therapy and associated with rapid recovery. ${ }^{15}$ However, the effect of dextrose is transit and relapses are common. ${ }^{13}$ Adding intramuscular glucocorticoids to dextrose may result in a more sustainable effect compared to dextrose therapy alone. Also, oral propylene glycol, that acts as a glucose precursor, is an effective therapy. ${ }^{13,15}$ In refractory cases, intramuscular long-acting insulin may improve metabolic acidosis by suppressing ketogenesis and fatty acid mobilisation. However, insulin should be given in combination with dextrose or glucocorticoid to avoid hypoglycaemia. Other treatments of refractory lactation ketoacidosis include continuous dextrose infusion and tube feeding. ${ }^{13}$

A human lactating female requires approximately $500 \mathrm{kcal}$ per day extra to meet additional energy requirements for milk production. ${ }^{16}$ In humans, lactation ketoacidosis is considered an extremely rare condition; the first case was described by Chernow et al. in the USA in 1982. ${ }^{2}$ They reported a 19-yearold lactating woman who presented to the emergency department with nausea, vomiting and abdominal pain. She was found to have high-anion gap metabolic acidosis and ketonuria. She had been consuming a low energy diet for five weeks prior to presentation and succeeded to loss around $12 \mathrm{~kg}$ body weight. In addition, she suffered from a urinary tract infection. She was treated with intravenous normal saline, 5\% dextrose and insulin. She was commenced on a 2,500 kcal per day diet and had resolution of ketoacidosis within 24 hours after admission. ${ }^{2}$

Lactation ketoacidosis is a rare condition that occurs in breastfeeding mothers and should be diagnosed after excluding all other causes of high anion gap metabolic acidosis. ${ }^{3}$ Currently, there are 15 cases of lactation ketoacidosis reported in the literature worldwide. ${ }^{2-4,8,17-27}$ Intravenous dextrose, electrolyte replacement and a balanced diet were the main treatments in all previously reported cases; sodium bicarbonate and insulin therapy were used in some cases. ${ }^{3,4,17,19,20}$ Some patients ceased breastfeeding while others managed to continue breastfeeding while receiving treatment for ketoacidosis. . $20,21,24^{2}$

Altered diet and reduced total energy in addition to exercise triggered lactation ketoacidosis in the first case presented while reduced oral intake because of severe gastroesophageal reflux and skipping meals were the precipitating factors in the second case. Both cases were treated with intravenous dextrose which resulted in resolution of metabolic acidosis within 24 hours. Both patients were able to continue breastfeeding their infants without reoccurrence of the condition. Overall, the presentation of these two cases, the rapid response to treatment and the outcomes were consistent with previously reported cases of lactation ketoacidosis. ${ }^{3}$ The authors have seen several cases of lactation ketoacidosis in their clinical practice and suspect this condition is more common than previously thought and that most cases are not correctly diagnosed.

\section{Conclusion}

Lactation ketoacidosis is considered an extremely rare cause of high anion gap metabolic acidosis. However, it may be under-diagnosed; therefore, it is important for the physicians and other health professionals to be aware of this condition. A patient may present with non-specific symptoms related to acidosis and hypoglycaemia including lethargy, headache, nausea and loss of energy. A low-energy diet and reduced oral intake due to concurrent illness are common precipitating factors. Intravenous dextrose and electrolyte replacement are associated with rapid recovery of the condition. Breastfeeding may be resumed after recovery from the metabolic acidosis and when the patient is able to consume a balanced diet. Overall, lactation ketoacidosis carries a good prognosis and the condition is very unlikely to recur.

\section{References}

1. Brubaker RH, Meseeha M. High anion gap metabolic acidosis. From: www.ncbi.nlm.nih.gov/books/NBK448090/ Accessed: Oct 2019.

2. Chernow B, Finton C, Rainey TG, O'Brian JT. "Bovine ketosis" in a nondiabetic postpartum woman. Diabetes Care 1982; 5:47-9. https://doi.org/10.2337/diacare.5.1.47.

3. Al Alawi AM, Falhammar H. Lactation ketoacidosis: Case presentation and literature review. BMJ Case Rep 2018; 2018. https://doi.org/10.1136/bcr-2017-223494.

4. Szulewski A, Howes D, Morton AR. A severe case of iatrogenic lactation ketoacidosis. BMJ Case Rep 2012;2012. https://doi. org/10.1136/bcr.12.2011.5409.

5. Kraut JA, Madias NE. Differential diagnosis of nongap metabolic acidosis: Value of a systematic approach. Clin J Am Soc Nephrol 2012; 7:671-9. https://doi.org/10.2215/ CJN.09450911.

6. Mubarik A, Jupalli A, Iqbal AM, Muddassir S, Eddib A. Isolated starvation ketoacidosis: A rare cause of severe metabolic acidosis presenting with a $\mathrm{pH}$ less than 7. Cureus 2019; 11:e4086. https://doi.org/10.7759/cureus.4086. 
7. Laffel L. Ketone bodies: A review of physiology, pathophysiology and application of monitoring to diabetes. Diabetes Metab Res Rev 1999; 15:412-26. https://doi.org/10.1002/(sici)15207560(199911/12)15:6<412::aid-dmrr72>3.0.co;2-8.

8. Gleeson S, Mulroy E, Clarke DE. Lactation ketoacidosis: An unusual entity and a review of the literature. Perm J 2016; 20:71-3. https://doi.org/10.7812/TPP/15-097.

9. Hammerbeck H, Holland MR. Starvation ketoacidosis: Treatment pitfalls. J Intensive Care Soc 2017; 18:265. https:// doi.org/10.1177/1751143716687593.

10. Dhillon KK, Gupta S. Biochemistry, ketogenesis. From: www. ncbi.nlm.nih.gov/books/NBK493179/ Accessed: Oct 2019.

11. Owen OE, Caprio S, Reichard GA Jr, Mozzoli MA, Boden G, Owen RS. Ketosis of starvation: A revisit and new perspectives. Clin Endocrinol Metab 1983; 12:359-79. https://doi.org/10.10 16/S0300-595X(83)80046-2.

12. Holtenius P, Holtenius K. New aspects of ketone bodies in energy metabolism of dairy cows: A review. Zentralbl Veterinarmed A 1996; 43:579-87. https://doi.org/10.1111/j.1439-0442.1996. tb00491.x.

13. Herdt TH. Overview of ketosis in cattle. From: www msdvetmanual.com/metabolic-disorders/ketosis-in-cattle/ overview-of-ketosis-in-cattle Accessed: Oct 2019.

14. Gordon JL, Leblanc SJ, Duffield TF. Ketosis treatment in lactating dairy cattle. Vet Clin North Am Food Anim Pract 2013; 29:433-45. https://doi.org/10.1016/j.cvfa.2013.03.001.

15. Stone N. Acetonaemia (Ketosis) of dairy cows. From: http:// agriculture.vic.gov.au/agriculture/pests-diseases-and-weeds/ animal-diseases/beef-and-dairy-cows/acetonaemia-ketosis-ofdairy-cows Accessed: Oct 2019.

16. Dewey KG. Energy and protein requirements during lactation. Annu Rev Nutr 1997; 17:19-36. https://doi.org/10.1146/annur ev.nutr.17.1.19.

17. Altus P, Hickman JW. Severe spontaneous 'bovine' ketoacidosis in a lactating woman. J Indiana State Med Assoc 1983; 76:392-3.
18. Heffner AC, Johnson DP. A case of lactation "bovine" ketoacidosis. J Emerg Med 2008; 35:385-7. https://doi.org/10.1 016/j.jemermed.2007.04.013.

19. Sandhu HS, Michelis MF, DeVita MV. A case of bovine ketoacidosis in a lactating woman. NDT Plus 2009; 2:278-9. https://doi.org/10.1093/ndtplus/sfp052.

20. Hudak SK, Overkamp D, Wagner R, Häring HU, Heni M. Ketoacidosis in a non-diabetic woman who was fasting during lactation. Nutr J 2015; 14:117. https://doi.org/10.1186/s12937015-0076-2.

21. Wuopio J, Schiborr R, Charalampakis G. [Severe ketoacidosis in breastfeeding woman with low energy and carbohydrate intake]. Lakartidningen 2015; 112

22. von Geijer L, Ekelund M. Ketoacidosis associated with lowcarbohydrate diet in a non-diabetic lactating woman: A case report. J Med Case Rep 2015; 9:224. https://doi.org/10.1186/ s13256-015-0709-2.

23. Greaney DJ, Benson P. Life-threatening lactation or "bovine" ketoacidosis: A case report. A A Case Rep 2016; 7:81-4. https://doi.org/10.1213/XAA.0000000000000350.

24. Sloan G, Ali A, Webster J. A rare cause of metabolic acidosis: Ketoacidosis in a non-diabetic lactating woman. Endocrinol Diabetes Metab Case Rep 2017; 2017. https://doi.org/10.1530/ EDM-17-0073.

25. Azzam O, Prentice D. Lactation ketoacidosis: An easily missed diagnosis. Intern Med J 2019; 49:256-9. https://doi.org/10.11 11/imj.14207.

26. Nnodum BN, Oduah E, Albert D, Pettus M. Ketogenic dietinduced severe ketoacidosis in a lactating woman: A case report and review of the literature. Case Rep Nephrol 2019; 2019:1214208. https://doi.org/10.1155/2019/1214208.

27. Seaton C, Sutherly K, Miller MA. Breastfeeding ketoacidosis: A rare but important diagnosis for emergency physicians to recognize. Am J Emerg Med. 2019; 37:374.e1. https://doi.org/10.1 016/j.ajem.2018.10.014 